This is the version of the article/chapter accepted for publication in Global Environmental Change, 2013, v23 (6). pp. 1594-1604, published by Elsevier. https://doi.org/10.1016/j.gloenvcha.2013.09.012

Re-use is subject to the publisher's terms and conditions

Accepted version downloaded from SOAS Research Online: http://eprints.soas.ac.uk/36245

\title{
Governance and technology transfer in the Clean Development Mechanism in India $^{1}$
}

Jon Phillips, Department of Geography, King’s College, London jonathan.phillips@kcl.ac.uk

Kasturi Das, Economic Environment and Strategy Area, Institute of Management Technology (IMT), Ghaziabad, Delhi-NCR, kasturi.das@gmail.com

Peter Newell, Department of International Relations, School of Global Studies, University of Sussex, Brighton BN1 9SN P.J.Newell@,sussex.ac.uk

Post-print version. For published version of this article see DOI: 10.1016/j.gloenvcha.2013.09.012

\begin{abstract}
Despite significant technological advances in emerging economies, the further development of clean energy technologies in developing countries remains crucial to reducing the emissions associated with economic development. In this paper we address two significant gaps in the growing body of literature that has assessed the role of the Clean Development Mechanism in promoting the transfer of clean technologies to developing countries. First, we present a qualitative analysis of the governance of the Clean Development Mechanism in India as a basis for understanding the extent to which and the ways in which governance might impact upon the likelihood that projects bring about technology transfer. Second, we provide a novel quantification of the level and nature of technology transfer that has occurred in Indian Clean Development Mechanism projects, based on insights from literature on technological capability building. We find that the Clean Development Mechanism in India has produced a negligible number of projects that promote technology transfer if technology transfer is understood as a process of learning about technology. Together these qualitative and quantitative analyses show how politics and governance have contributed to the current form of the Clean Development Mechanism market in India, in which processes of building indigenous technological capabilities have been neglected.
\end{abstract}

\section{Keywords}

Clean Development Mechanism (CDM); Technology Transfer; Innovation; India; Clean Energy; Governance

\section{Highlights}

Highlights the role of politics in shaping the Clean Development Mechanism and technology governance in India

Presents a novel typology of technology transfer in Clean Development Mechanism projects Finds technological learning and capability building in Indian Clean Development Mechanism projects to be minimal

Explores the extent to which governance has shaped the neglect of technological capabilities Discusses implications for the use of climate finance in developing technological capabilities

\footnotetext{
- Some of this research was conducted under the Governance of Clean Development Project (www.clean-development.com) and was funded by Economic and Social Research Council (ESRC) grant RES-066-27-0005. We would also like to thank David Ockwell and three anonymous referees for their comments on an earlier version of this paper.
} 


\section{Introduction}

The transfer of low carbon technologies from developed to developing countries has been a key sticking point in international climate change negotiations during and since the negotiation of the United Nations Framework Convention on Climate Change (UNFCCC) in 1992. Technology transfer has been embroiled in disputes over North-South trade relations, foreign direct investment, historical responsibility for climate change and the protection and sharing of intellectual property rights. It continues to be a hotly contested subject amid current discussions on a Technology Mechanism and a Climate Technology Centre and Network (Blanco et al. 2012). While not created as a vehicle for technology transfer as such, the Kyoto Protocol's Clean Development Mechanism (CDM) has subsequently been promoted as one means through which climate-friendly technologies may be transferred to developing countries.

By examining the case of India, this paper explores the extent to which the CDM has contributed to technology transfer, the nature and depth of such transfer, and the political factors that govern technology transfer under the CDM. In particular, we explore the extent to which CDM governance might impact upon patterns of technology transfer and the ways in which it does so. Our point of departure is that the reality of clean technology transfer is more complex than suggested by approaches which focus exclusively on governance by state-led processes or free markets (Forsyth 2007), since even seemingly private market transactions are structured, regulated and incentivised by particular modes of governance. Structures of CDM governance have the potential to impact technology transfer in CDM projects in a number of ways. National government authorities in developing countries are expected to screen and approve CDM projects to ensure that they contribute to local sustainable development, one aspect of which is whether projects are likely to involve technology transfer. Governments have a large degree of discretion over how to interpret and enforce sustainable development requirements under the $\mathrm{CDM}$, based on their fit with nationally and locally identified priorities, and decisions over questions of control and ownership of the knowledge associated with the operation of clean technologies. Given the very different contexts that characterise national CDM decision-making processes (Fuhr and Lederer 2009), it is critically important to understand how forms of governance affect the likelihood that superior forms of technology transfer occur.

Several empirical studies have examined the extent to which the CDM contributes to technology transfer, including evaluations commissioned by the UNFCCC (e.g. Haites et al., 2006; Seres, et al., 2007, 2009; Dechezleprêtre et al., 2008; Seres and Haites, 2008; Dechezleprêtre et al., 2009;; UNFCCC, 2010, 2011a, 2012). Some have also begun to suggest the importance of host country characteristics in determining relative rates of technology transfer (Haites et al 2012; Schmid 2012; 
UNFCCC 2012). However, this literature has, in our view, failed to adequately address two important aspects of technology transfer under the CDM. First, the methodologies employed in quantitative comparative assessments of technology transfer under the CDM have not reflected important advances in the understanding of the process of technology transfer.

Second, analysis of technology transfer has not yet recognised the importance of governance, politics and institutions in understanding how, when and whether the CDM is capable of producing social and development benefits. While an extensive body of literature has assessed Indian climate change policy and the CDM in India (e.g. Benecke 2009, Michaelowa and Purohit 2007; Sirohi 2007), it often neglects detailed analysis of political processes: the actors and institutions involved in decisionmaking and the relations of power which underpin them. Meanwhile, although the importance of institutional design and effective governance at the international scale is acknowledged in debates about the design of the Technology Mechanism and the Climate Technology \& Network (CTC\&N), in the prior experience of the UNFCCC and Global Environment Facility (GEF), and increasingly in debates about the CDM (Boyd 2009; Phillips and Newell 2013), we still lack an understanding of how domestic political contexts and relations of power impact upon what types of technology get transferred and on whose terms.

To address these gaps, this paper integrates data from a novel quantitative assessment of the rate and nature of technology transfer under the CDM (Das, 2011) with a qualitative assessment of the nature and practice of CDM governance in India. We explore the extent to which the latter account of a laissez-faire approach to ensuring CDM co-benefits including technology transfer are delivered, offers clues to the poor performance revealed by the quantitative analysis. We argue that governance processes have potentially significant implications for when, why and how technology transfer may or may not be forthcoming under the CDM. While India has been among the major host countries of the CDM projects, international comparative analyses have found the rate of technology transfer in Indian CDM projects to be among the lowest (Seres, et al. 2007, 2009; Dechezleprêtre et al., 2008; Seres and Haites, 2008; Dechezleprêtre et al., 2009; UNFCCC, 2010, 2011a, 2012; Das, 2011). This is despite the strong emphasis on international technology transfer by India's public institutions in climate change negotiations and forums on the CDM (Planning Commission 2003; UNFCCC 2011b). This discrepancy between success in attracting projects and high expectations of technology transfer on the one hand, and poor performance on the other, calls for further explanation.

Our approach to examining the politics of policy-making in practice allows us to address the relative neglect in academic literature of informal governance practices beyond institutional mandates and official CDM project approval criteria. These issues require detailed attention since many assumptions about the way governance systems shape technology transfer may not hold true in practice (Disch 
2010). This helps to explain the discrepancy we find in India between the rhetoric on the importance of technology transfer to national development goals, and the reluctance in practice to use policy measures and tools to deliver on this ambition through the CDM. In the vacuum created by a laissezfaire approach to the governance of technology transfer, we find that market-based factors predominately determine the level of technology transfer in India. Interview material with key actors and previous studies also suggests that local governance institutions, including state (provincial) governments, are not currently able to compensate for this governance vacuum with regard to technology choice, oversight and control.

The paper proceeds as follows. Section 2 provides a brief discussion on the conceptual framework of technology transfer adopted in our analysis, utilising insights from literature on innovation and technological capability building. Section 3 describes the current landscape of Indian CDM governance in practice, based on 38 interviews conducted in New Delhi in September 2010 and 2011 with staff in government ministries and authorities, project developers, consultants, private foundations, financiers, bilateral and multilateral donors, non-governmental organisations and civil society organisations, and supplemented by secondary literature. Section 4 provides a quantitative description of the level and nature of technology transfer in Indian CDM projects. Based on the conceptual framework outlined in Section 2, we present an alternative operational definition of technology transfer under the CDM, which shows that India has hosted very few projects that promote superior forms of technology transfer. Finally, Section 5 discusses the complex relationship between governance, politics and the state of technology transfer under the CDM.

\section{Defining Technology Transfer:}

\subsection{Conceptual framework for technology transfer}

This paper uses an approach to technology transfer under the CDM informed by a growing body of literature on technological innovation in developing countries. Studies have shown that for developing countries to 'catch up' with technological innovations in advanced economies, policies must promote learning about technologies among the 'recipients' of technology. It is important for recipients of technology to build the capabilities to adapt technologies to local conditions and circumstances, and to generate innovations (Nelson and Winter, 1982; Mowery and Rosenberg, 1989; Lall, 1992; 1993). Understood in these terms, technology is not constituted merely in its embodied forms of hardware such as turbines, transistors, stoves, or pistons. Rather it is directly associated with the knowledge of its design and use. To build the all-important technological capabilities among recipient firms and communities, transfer of technology needs to be accompanied by transfer of the tacit elements of 
knowledge: those that are difficult or impossible to transfer in written forms such as blueprints, patents, or training manuals (Lall, 1993). Applied learning about technologies is essential to identify and gain access to clean technologies, to use them appropriately, to adapt them to local conditions, and to improve upon them.

The development of technological capabilities is therefore a continuous process of accumulating skills within a firm or community, often by taking advantage of knowledge from external sources such as foreign companies (Lall 1992). The prospects for technological learning are, however, mediated by the 'absorptive capacity' of a firm or community: 'the ability to recognize the value of new external knowledge, assimilate it, and apply it to commercial ends' (Cohen and Levinthal 1989; 1990). This absorptive capacity is largely a function of the knowledge held within an organisation and without it, the prospects for technological learning are low.

In practice, technology transfer for climate-friendly technologies has been interpreted in a greater variety of ways than as a process of technological learning. The definition provided by the Intergovernmental Panel on Climate Change (IPCC, 2000) is the closest to an official statement on how technology transfer is conceived in international climate policy. Technology transfer is described as a broad set of processes covering the flow of know-how, experience and equipment for mitigating and adapting to climate change among different actors. The IPCC (2000) definition follows much of the literature cited above in highlighting the importance of learning to understand, utilise and replicate technologies, including the capacity to choose and adapt technologies to local conditions and integrate them with indigenous technological knowledge systems. Yet the IPCC emphasis on technological know-how arguably does not capture the range of necessary elements for the development of technological capabilities in developing countries. This includes deeper capabilities, such as knowwhy, which connotes an understanding of the principles of technologies (Lall, 2004). These organisational assets are likely to be important for developing countries to leapfrog carbon-intensive technologies and avoid 'lock-in' to carbon-intensive processes (Bell 2009). This broad understanding of technological learning informs the operational definition of technology transfer under the CDM that we mobilise in Section 4.

\subsection{The international politics of defining technology transfer}

In contrast to the IPCC, the UNFCCC has not adopted a working definition of technology transfer. The variety of interpretations of technology transfer in the UNFCCC mechanisms reflect the politics of negotiating technology transfer through international climate change negotiations. Developed and developing countries have long been engaged in battles over access to low carbon technologies. These conflicts have been rooted in conflicting discourses of technology development favoured by 
developing countries, and technology diffusion favoured by Annex I countries that are home to most technology developers. Neither of these discourses is able however to adequately capture the requirements to enhance technological capabilities in developing countries (Ockwell et al. 2010).

The opposing approaches are based on conflicting ideas over what technology transfer is, and therefore what it is to achieve. It is within this context that the flexible mechanisms of the Kyoto Protocol (1997) were negotiated and the CDM came to take the role it has in debates over technology transfer. The creation of the CDM is closely tied to trends within the UNFCCC to substitute demands over technology transfer for North-South financial transfers, and the gradual displacement of ideas of technology transfer as a state-led process (Forsyth 1999). The modalities of the CDM, defined in the Marrakesh Accords of 2001, have arguably circumnavigated these politics, identifying technology transfer as one of any number of contributions to the vague notion of 'sustainable development' to be defined and prioritised by the host countries of CDM projects. Beyond providing a potential new financial incentive for technology transfer, the CDM provided little guidance on how the mechanism would overcome existing political problems associated with promotion of technology transfer among numerous private entities. These international politics of technology transfer then have opened up the space within which governance of technology transfer under the CDM has come to be shaped by national and sub-national level processes in CDM host countries. It is these processes that we turn to next.

\section{The Governance of Technology Transfer in the Indian CDM}

\subsection{India's Technological Priorities}

Given that developing countries are not considered to be innovating at the technological 'cutting edge' in most clean technology sectors, there remains a need for countries such as India to enhance its indigenous capabilities (Mallet et al. 2009; Watson et al. 2011; Dechezleprêtre et al. 2011). Despite recent examples of Indian companies entering partnerships to enhance local technological development (Lema \& Lema, 2012), significant innovations are likely to be required for the country to move beyond its current target for 20-25 percent reduction in emissions intensity between 2005 and 2020 (CSE 2010; Planning Commission, 2011). The extent to which international climate finance mechanisms can help address this challenge will reflect, in part, the extent to which technological capability building is facilitated both through and beyond the CDM.

India has outlined a potential role for the CDM that strongly aligns with its 'co-benefits' approach to domestic climate action. This approach broadly aims to combine climate finance with government policies to 'provide an impetus and play a vital role in promoting projects with significant co-benefits 
in terms of sustainable development for more challenging policy goals' (TERI 2005:78). In this respect, early assessments of the CDM in India identified the limited role that CDM finance alone could play in promoting most renewable energy technologies, due to the high incremental costs of some technologies and the favourable domestic regulatory environment which existed for others (TERI 2005). Yet India's 2003 National Action Plan for Operationalizing the CDM emphasises a more ambitious role for the CDM to contribute to technology transfer, emphasising the importance of indigenous capability building (Planning Commission, 2003: 75):

\footnotetext{
...the ultimate goal of any action in the field of transfer of EST (Environmentally Sound Technologies) should not be just applying particular technological solutions, but to enhance the capabilities of developing countries to assess the need, select, import, assimilate, adapt and develop the appropriate technologies... In fact provision for capacity building in the long run should be made mandatory in any TT [Technology Transfer] with crosschecks built-in for verification.
}

In negotiations over CDM reforms at the UNFCCC Conference of Parties, however, the Government of India has aimed to expand the range of technologies under the mechanism and enhance access to foreign technologies by reducing the cost of doing business for project developers (Vihma, 2011). This approach is similar to the country's position in the often polarised North-South politics of international trade and climate change negotiations, where Indian negotiators have emphasised access to European and North American technological hardware (Ockwell et al. 2010; MoEF 2012). Within India, there has been disappointment over the extent to which the country's prosperous CDM market has actually provided access to new foreign technological hardware (Government of India 2008). However, more significant for our purposes here is the disconnect between the normative goal of domestic technological capability building and that of enhancing access to primarily foreign hardware and finance. We outline below the many institutions and actors that have governed the CDM in India according to the latter.

\subsection{India's Designated National Authority and the Everyday Governance of the CDM}

Responsibility for the promotion and assessment of the sustainable development contribution of CDM projects lies with the host country through the Designated National Authority. The Designated National Authority recommends approval criteria on licensing, stakeholder consultation, feasibility, and risk assessments to be approved by the central government. However, the early articulation of technology transfer by the Planning Commission (2003) discussed above has not translated into clear guidance in CDM project approval criteria in India. Rather, the Designated National Authority has taken a more laissez faire approach to project approval criteria, described by the former Member Secretary of the Designated National Authority as a 'holistic' set of 42 sustainable development 
criteria (Interview with Member Secretary of Indian Designated National Authority). With respect to technology transfer, the criteria state only that: 'CDM project activity should lead to transfer of environmentally safe and sound technologies that are comparable to best practices in order to assist in upgradation of the technological base' (MoEF nd).

The Designated National Authority have also gained a reputation for light-touch procedures in its operationalisation of formal project approval. Close observers have suggested that the process of weighting and assessing the 'parameters of sustainable development' in social, technological and developmental terms is not explicit (Interview with Project Officer, carbon project labelling organisation) such that technology transfer does not receive special consideration in the project approval process (Interview with CDM project approval official). Some actors maintain that the Designated National Authority 'does not evaluate; rather it checks the fit with national priorities' (Interview with Indian industry body representative), while critics of the process suggest a more unhealthy degree of collusion between project developers and national regulators (Interview with NGO Deputy Director). The Member Secretary of the Designated National Authority has conceded that one of the primary purposes of the institution is to check that the legal clearances are in place, and that a failure to demonstrate sustainable development benefits has not been the basis for rejecting projects (Interview with Member Secretary of Designated National Authority).

Given the large number of projects developed in India, the Designated National Authority is also highly dependent on what project developers claim in Project Design Documents (PDDs). This is problematic where - according to some observers - underestimating the level of indigenous technological capability is common practice among project developers in order to demonstrate the technological 'additionality' of projects (Interview with NGO Deputy Director). Where the transaction costs of project development are high, CDM finance is typically viewed by project developers as means to mitigate the risk of developing viable projects. The extent to which the CDM really provides this additional incentive is contentious, with many NGOs claiming that CDM registration of existing renewable energy projects has failed to add value to renewable energy and energy efficiency policies already provided by states and the central government (Interview with NGO Deputy Director; see also Schiermeier, 2011).

For sector-specific information, such as that related to specific technologies, the Designated National Authority is reliant on its approval committee of representatives from relevant government ministries. Participants on the approval committee confirm that all projects are normally supported, particularly renewable energy projects which are assumed to demonstrate 'sustainable development' by virtue of their choice of technology alone. Despite the mandate to set sustainable development criteria, the role of the Designated National Authority in India reflects the fact that, in practice, there is little appetite to 
steer project developers toward technology transfer, nor to promote partnerships for technological learning.

\subsection{Governance within Government}

The Designated National Authority and its institutional host the Ministry of Environment \& Forests (MOEF) are not the only sites of CDM governance or clean technology governance in India, however. The CDM enters existing landscapes of policy priorities, bureaucratic battles and processes of decision-making.

The value that different ministries attach to the CDM is important in determining the resources they commit to it, and rests on their judgement of the value that the CDM brings to existing and emerging policy initiatives. For some ministries, the CDM serves as a financial transfer mechanism: one possible way of enhancing and extending the goals set out in national policies, such as promoting rural electrification (Interview with Director, Ministry of Environment and Forests). Other ministries place little importance on the CDM. The CDM currently receives little attention in the Ministry of Power for example, but may attract greater interest as CDM modalities on Carbon Capture and Storage are amended and hence come to align with the Ministry's core mandate for centralised, gridconnected, fossil fuel generation of power (Interview with Director, Ministry of Power).

However, more significant for technology transfer is the unification of different parts of government around the financial framing of the potential contribution of the CDM. This framing positions the $\mathrm{CDM}$ as a supplementary source of finance to extend domestic targets for clean energy, rather than a facilitator of novel technological partnerships that might boost India's capacity to scale up renewable energy through enhanced indigenous capabilities. For example, the Ministry of New and Renewable Energy (MNRE) foresees a significant role for the CDM and other sources of international climate finance in increasing the scale of India's National Solar Mission, an ambitious scheme to establish India as a leading economy in knowledge and manufacturing of various solar technologies, without expecting that the CDM will be the vehicle for delivering new solar technologies, nor building capacity around them (Interviews with Directors, Ministry of New and Renewable Energy). The prospects for technological capability building are thus limited by this narrower framing of the CDM's potential.

\subsection{Multi-level governance}

The everyday governance of the CDM is also not restricted to New Delhi institutions. Ultimately many of the key issues which affect the governance of the CDM and technological development are 
state subjects (TERI 2005). State governments are responsible for promotion of CDM projects and providing relevant administration, such as issuing environmental clearances or entering into power purchase agreements with electricity providers, through which the primary financial incentive for renewable electricity generation is provided. For project developers then, the CDM represents just one set of governance challenges which also includes land policy, the consistency of state-level renewable energy tariffs, grid connections, taxes on equipment imports and so on, which all directly or indirectly impact upon the assurance mechanisms and transaction costs of potential collaborative partnerships for technology transfer (Interview with wind technology company). Business perceptions of the relative strength of state level governance and 'business friendly' policies also shape whether technological partnerships and learning are likely to be generated in certain states and local environments.

International institutions also shape the likelihood of technology transfer taking place. The first category of international interventions encompasses those that have attempted to stimulate market growth and reduce transaction costs for project development. These include The World Bank's Prototype Carbon Fund, which has attracted criticism within India for failing on its own terms of market facilitation - offering low prices for carbon credits, stringent processes, a lack of capital, and poor interest rates (Interviews with carbon consultant; and Director of Ministry of New and Renewable Energy). The second category of interventions address governance deficits though efforts to improve the procedural operations and capacity of public CDM institutions or project developers. These include efforts by the Asian Development Bank to shape the sectoral direction of CDM project development through toolkits. While addressing perceived market weaknesses, these two modes of intervention do not target the promotion of capability building per se and are unlikely to generate technological learning in CDM projects

The third, and least common, type of international interventions are those that provide more active intervention to create partnerships, which might enable technology transfer. The German international development agency GIZ for example has operated from within the India Bureau of Energy Efficiency, participating directly in the market by working with Small and Medium Enterprises to set up projects with particular local benefits, and facilitating the sale of the credits to German buyers. While these interventions are more attuned to creating conditions for technological partnerships, the process is a resource intensive one demanding a lot from public agencies in the process of facilitating technology transfer among private entities. The CDM model in these cases differs little from previous state-led models of technology transfer that have relied heavily on public resources to promote a niche set of projects that promote capability building (Forsyth 1999).

\subsection{Summary}


We have found little evidence of governance systems in place in India that are able to enhance the likelihood that CDM projects contribute to the building of technological capabilities developed through domestic public policy and private efforts. Rather, there exists a discourse around the scalingup of existing technologies under domestic initiatives through the provision of finance and associated technological hardware, but few means for realising technology transfer in practice. Considering the slow, complex process of technology transfer outlined in Section 2, there appears to be little scope for technological learning in the linear model of innovation that is adhered to by the CDM and reinforced by the way in which it is governed in practice in India. In particular, our approach has illustrated how governance systems at several scales help to structure the incentives and disincentives that are provided to engage in particular types of technology transfer; the perceptions of (financial) risk associated with particular investments; and the screens in place at national and sub-national level to ensure that sustainable development outcomes are delivered and that claimed beneficiaries actually benefit from the projects approved by the Designated National Authority, a theme we return to in section 5 of the paper.

The following section assesses the level and type of technology transfer that has been achieved in India under the particular governance landscape described above. Rather than establishing any direct causal link between particular features of the governance system outlined above and the specific technology transfer outcomes described below- which would be elusive and tenuous at best - our approach offers a framework for understanding how governance and politics shape technology transfer, the context in which it occurs, and which type of technology transfer results.

\section{Assessment of Technology Transfer in Indian CDM Projects}

\subsection{Methodology}

\subsubsection{Typology of Technology Transfer}

The following section provides an empirical assessment of technology transfer in Indian CDM projects to identify the possible implications of the governance processes that we describe above. The analysis is based on all 326 Indian Project Design Documents drawn from a dataset of the first one thousand registered CDM projects (between November 2004 and March 2008), described in full by Das (2011). We apply an operational definition of technology transfer under the CDM that adopts a hierarchical typology. In this operational definition, three distinct types of technology transfer are differentiated by their transformative effect on technological capabilities, reflecting the conceptual framework outlined above (Das 2011). This definition has been devised to be more attuned to the 
conceptualisation of technology transfer provided by the IPCC (2000) and many developing countries governments themselves, including India (Planning Commission 2003). It also encompasses some elements of technology transfer that go beyond the know-how of operating technological hardware and contribute towards deeper levels of technological capability building.

We consider a CDM project to contribute to technology transfer if it fulfils any of the three conditions outlined in Table 1. Equipment import alone is not considered to be technology transfer, unless such import is accompanied by technological capability building in some way or the other. In this respect the typology differs considerably from most previous studies (Haites et al., 2006; Seres, et al., 2007; Dechezleprêtre et al., 2008, 2009; Seres and Haites, 2008; UNFCCC, 2010; 2011a; 2012). We exclude such projects on the basis that the purchase of foreign technology alone is not conducive to technological capability building or strengthening innovation performance (Li, 2011). At a very basic level, such import must be accompanied by transfer of operation and maintenance knowledge. This is categorised as Type 3 technology transfer, in which capability building is possible, but is confined to basic levels of operational knowledge only.

Under stricter conditions, training on operations and maintenance is not considered sufficient to significantly increase technological capabilities among recipients of technology or promote localised innovation. In contrast to Type 3 then, the conceptualization of Type 1 and Type 2 technology transfer is based on the understanding that effective technology transfer is an interactive process between the providers and the recipients of technologies - a process that depends to a large extent on the recipient efforts and investments in capability building. Type 2 technology transfer relates to adaptive in-house Research and Development, where a firm combines external and internal sources of learning (Cohen and Levinthal 1989). This category reflects that the efficacy with which imported technologies are used and adapted depends on local effort to deepen the absorptive base (Lall 2002). Finally, Type 1 captures technology developed specifically for a CDM project through foreign collaboration. Type 1 may be regarded as analogous to collaborative research and development with foreign entities, which also requires substantial interaction between the providers and recipients of technologies. 
Table 1. Operational definition of technology transfer in CDM projects - a hierarchical typology

Type 1 A host country entity develops a technology specifically for a CDM project in collaboration with a foreign entity

Type 2 Technology and/or equipment import is accompanied by in-house technological efforts by the host country project participant towards adapting or improving upon the imported technology and/or equipment

Type 3 Technology and/or equipment import is accompanied by training by foreign entities on operation and maintenance of the imported technology and/or equipment.

Source: Das (2011: 5)

The methodology adopted here differs from most of the other Project Designed Document-based studies in some significant respects. First, it does not record the explicit claims to technology transfer in project design documents, captured by keyword searching (e.g. UNFCCC 2012). Rather, each project design document has been scrutinized in full and categorised according to the operational definition. Close reading of Project Design Documents has revealed great variation in the interpretation of technology transfer by CDM project developers, often including contradictory claims within Project Design Documents (Das 2011). .

\subsubsection{Limitations}

The typology and methodology adopted here include some weaknesses that reflect (i) data sources and (ii) the challenges of capturing the nature of technological capability building. First, any study based on analysis of project design documents is restricted to the intended activities pertaining to technology transfer under the CDM projects, rather than their implementation and outcomes. However, we are cautious about the findings of recent studies that employ post-implementation surveys to complement analysis of Project Design Documents. The methodology employed by these studies is based on self-reported and undefined claims, and is itself problematic. So too are associated changes to the reporting of rates of technology transfer under the CDM, which has resulted in upward revisions in recent years (UNFCCC, 2011a; 2012). Hansen's (2011) rare ex-post study of technological learning in $\mathrm{CDM}$ projects provides particular reason to doubt the assessment of technological learning outcomes based on project design documents: only one of thirteen Malaysian projects in which technological learning beyond import occurred was originally planned.

The second methodological limitation is associated with capturing technology transfer as a long term process of capability building. This limitation is shared by all comparative assessments of technology 
transfer rates under the CDM to date. Type 1 and Type 2 represent measures of technology transfer as discrete events (projects), rather than a process. These categories are therefore not able to capture the potential impact of a CDM project beyond its own project boundaries, such as the potential for learning and capability building to contribute to future innovation by a firm or community based on processes initiated during a CDM project. Given the long term nature of technological innovation, Type 1 and Type 2 are therefore only basic measures of the extent to which CDM projects could facilitate improvements to host country technological capabilities.

Analysis of project design documents is inherently limited as a means to measure project outcomes. Yet this study is less sensitive to these limits than others because we do not make the same claims to measure project outcomes. Rather, the integration of our qualitative and quantitative analysis is more focused on the role of governance in putting in place the conditions that would allow technological learning to occur. Type 1 and Type 2 technology transfer then represent a strategic compromise in addressing the methodological challenges above. It allows comparison with existing literature and official UNFCCC assessments on their own terms of project-based assessment, but also allows for alternative measures of the role of CDM projects in driving technological learning. To capture technology transfer as a process of technological learning is a priority for further research in this area, and requires significant innovations away from methodologies that are amenable to large, international comparative assessments and the role they play in informing CDM policy evaluation. Rather, research methods are required that can capture the long term processes of knowledge adoption, adaptation, and innovation; methods that can be tension with the urgency of policy frameworks, and with the current quantitative framework for assessment of the CDM's contribution for technology transfer.

\subsection{The Global Record of Technology Transfer under the CDM}

Our analysis of Indian CDM projects selects data from a broader global database of projects: a multicountry analysis of technology transfer in the first one thousand registered CDM projects, hosted by 49 countries and in 23 different project categories (Das 2011). Although China later came to dominate the CDM project pipeline, India hosted the largest proportion of the first thousand registered projects with 326 projects, followed by China, Brazil and Mexico. Table 2 presents a summary of technology transfer by host country. Das's analysis estimates that 26.5 percent of CDM projects demonstrate evidence of technology transfer, lower than the estimates of previous studies which find approximately a third of projects to make explicit claims of technology transfer (Haites et al., 2006; Seres, et al. 2007; Dechezleprêtre et al., 2008, 2009; Seres and Haites, 2008; ; UNFCCC, 2012). Although an identical set of Project Design Documents was not analysed, we consider this difference to be primarily attributable to the exclusion of equipment import from the operational definition of technology transfer. Likewise, though the study is limited to the first one thousand registered CDM 
projects, we consider this analysis to have continued relevance. It is notable, for example, that studies employing less stringent definitions of technology transfer have documented steady rates of decline in major host countries, including India (Seres et al. 2009; UNFCCC 2012; Murphy et al 2013).

However, more significant than the aggregate figures are the almost negligible levels of superior forms of technology transfer recorded using this typology (Table 2, Column 4). Of 265 projects demonstrating technology transfer, 259 are limited to providing only a basic or operational level of technological learning and capability building, i.e. Type 3 technology transfer (Column 5). Only six out of one thousand projects were found to contribute towards higher levels of technological capability building, i.e. Type 1 or Type 2 technology transfer. This suggests that globally the CDM is failing to drive technology transfer as a process of technological learning and capability building. 
Table 2. Technology transfer by host country and associated annual emission reductions

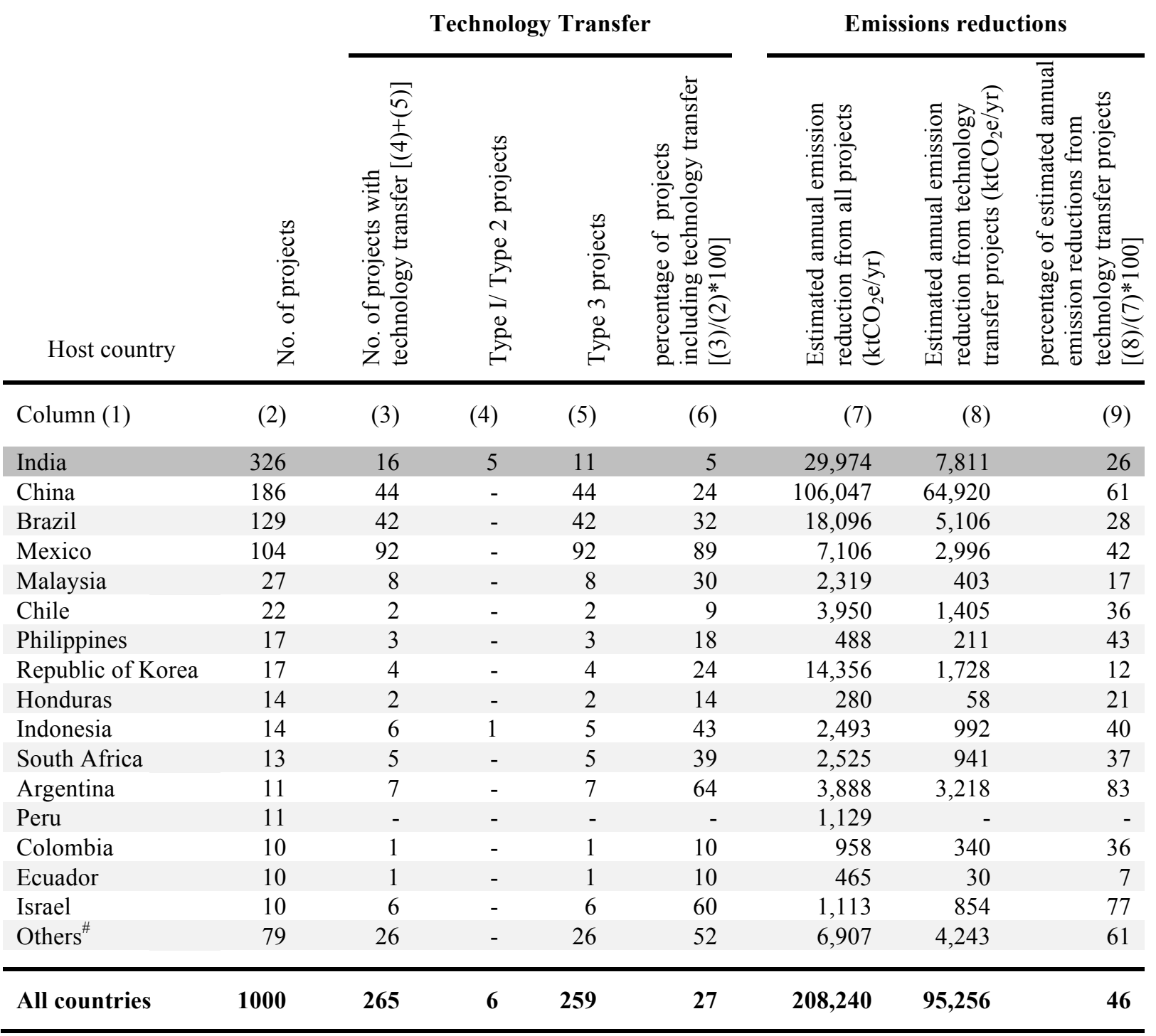

Source: Das (2011)

Notes:

1. Figures rounded to the nearest integer value

2. Data for the first 1000 registered CDM projects, March 2004 - November 2008

\# Others category includes 33 host countries each hosting fewer than ten projects

- Denotes zero value

\subsection{Technology Transfer in Indian CDM projects}

Our findings corroborate those of previous studies that find technology transfer through the CDM in India to be substantially lower than the global average and other major host countries (Table 2, Column 6) (e.g. UNFCCC, 2012). However, the rate of technology transfer in India (5 percent) is also found to be considerably lower than previous estimates have suggested: 13 percent compared to 16 percent in the UNFCCC studies. This is attributable primarily to the exclusion of equipment import 
alone from the operational definition of technology transfer. As displayed in Table 3 (Column 3) if equipment import alone were considered as technology transfer, in line with previous studies, the extent of technology transfer would have been much closer to the previous UNFCCC estimates (UNFCCC 2010; 2011a). Despite the very low rates of technology transfer recorded in our study for India, the country is also found to host five of the six projects worldwide that demonstrate superior forms of technology transfer under the CDM (Table 2, Column 4). While this figure is too low to form the basis of generalisations, it invites closer scrutiny of the Indian case.

Indian CDM projects are spread across 15 project types, of which five categories account for 85 percent (276) of projects (Table 3, Column 2). Biomass Energy accounts for more than a third of all the projects hosted, followed by Wind, Energy Efficiency Own Generation, Hydro, and Energy Efficiency in Industry. Technology transfer is particularly low in the top four categories by project type (3-8 percent), and slightly higher in the fifth category - Energy Efficiency in Industry - at 17 percent (Table 3 Column 4). It is notable that the use of imported technology/equipment is also very low among the top four categories (Table 3, Column 3), a key reason why even Type 3 technology transfer is very low.

Low levels of use of foreign technologies is attributable at least partially to the availability of domestic renewable energy technologies in these categories, as often outlined explicitly in the Project Design Documents of the projects concerned. The Biomass Energy category predominantly involves the use of mature technologies used in cogeneration or captive power generation projects in various industries, particularly the sugar industry. The majority of Energy Efficiency Own Generation projects (29 of 38 projects) utilise heat recovery systems in sponge iron production, technology that is readily available in India, and only one of the 29 projects is registered as using imported technology. Energy Efficiency in Industry has seen higher rates of technology import (31 percent, 11 projects), with three of these projects qualifying as Type 3 technology transfer by virtue of operation and maintenance training.

The Energy Efficiency in Industry category also includes three of India's five projects that promote superior technology transfer (Type 1 and Type 2). Two projects are in ammonia production units, one is in a petroleum refinery unit. The remaining two superior projects are in Biogas and Solar. The Solar project qualified as a Type 1 technology transfer project due to the technological collaboration with a German public agency that aimed to establish local manufacturing capacity in solar cooker technology that was relatively new to India. The project activity involves the implementation and operation of solar community kitchens and similar solar steam applications in various regions in India. This project was hosted by a private limited company that specializes in development of solar cooker technologies through foreign collaboration. It was also certified by the Gold Standard carbon credit labelling 
scheme, which aims to financially reward projects that demonstrate significant contributions to sustainable development in host countries.

The remaining four projects with superior technology transfer relate to energy conservation or savings. Among these four, three are hosted by leading Indian corporate firms, and another is hosted by a leading cooperative. Three of these projects are categorised as Type 2, employing in-house technological effort. The fourth qualifies as Type 1, involving in-house development of a retrofit technology specifically for the project by the Indian project participant through technological collaboration with a European firm. Against a backdrop of Government policy measures to incentivise energy saving and conservation in the industrial sector (Yang 2006), a number of industrial units in India have set up in-house research and development units to meet the technological needs of production centres, including on energy efficiency improvements. In particular, the corporate firms and the cooperative society involved in the projects with superior technology transfer have been engaged in various long term in-house energy saving innovations as part of efforts on energy conservation and management.

These cases of superior technology transfer in CDM projects suggest, perhaps unsurprisingly, that in the handful of cases where the CDM is promoting technological capability building in India, it occurs mainly among recipients that are already well positioned to utilise the opportunity through existing absorptive capacity created under the policy and governance framework beyond the CDM. Thus, in these cases projects with superior technology transfer have not demonstrated an impact on technological capability building where it was previously absent. Rather, these can be said to have furthered an on-going process of technological capability building by part-financing in-house and/or collaborative technological efforts. 
Table 3: Technology Import and Technology Transfer in India by project type

\begin{tabular}{|c|c|c|c|c|c|}
\hline Project type & $\begin{array}{c}\text { Total } \\
\text { projects }\end{array}$ & $\begin{array}{l}\text { Projects } \\
\text { with } \\
\text { technology } \\
\text { and/or } \\
\text { equipment } \\
\text { import }\end{array}$ & $\begin{array}{c}\text { Projects with } \\
\text { technology } \\
\text { transfer: } \\
\text { Types } 1,2,3\end{array}$ & $\begin{array}{c}\text { Type } 1 \& \\
\text { Type } 2 \\
\text { projects }\end{array}$ & $\begin{array}{r}\text { Type } 3 \\
\text { projects }\end{array}$ \\
\hline Column [1] & [2] & [3] & [4] & {$[5]$} & [6] \\
\hline Biomass energy & 113 & $7 \quad(6)$ & $2(2)$ & - & 2 \\
\hline Wind power & 52 & $4 \quad(8)$ & $1(2)$ & - & 1 \\
\hline $\begin{array}{l}\text { Energy efficiency own } \\
\text { generation }\end{array}$ & 38 & $3 \quad(8)$ & $1 \quad(3)$ & - & 1 \\
\hline Hydroelectric & 38 & $1 \quad(3)$ & $-(-)$ & - & - \\
\hline Energy efficiency industry & 35 & $11 \quad(31)$ & $6(17)$ & 3 & 3 \\
\hline Cement & 13 & $-\quad(-)$ & $-(-)$ & - & - \\
\hline Biogas & 9 & $1 \quad(11)$ & 1 (11) & 1 & - \\
\hline Fossil fuel switch & 9 & $4 \quad(44)$ & $1(11)$ & - & 1 \\
\hline Energy efficiency supply side & 8 & $-\quad(-)$ & $-(-)$ & - & - \\
\hline Hydroflurocarbons (HFCs) & 4 & $4(100)$ & $3(75)$ & - & 3 \\
\hline Landfill gas & 3 & $1 \quad(33)$ & $-(-)$ & - & - \\
\hline Energy efficiency service & 1 & $1(100)$ & $-(-)$ & - & - \\
\hline Fugitive & 1 & $1(100)$ & $-(-)$ & - & - \\
\hline Solar & 1 & $-\quad(-)$ & $1 \quad(100)$ & 1 & - \\
\hline Transport & 1 & $1(100)$ & $-\quad(-)$ & - & - \\
\hline All project types & 326 & 39 (12) & $16(5)$ & 5 & 11 \\
\hline
\end{tabular}

Notes:

1. Figures in the parentheses display adjacent values as percentages of all projects of that type.

- Denotes zero value

Technological capability building through CDM projects appears to also have been concentrated geographically. These projects have supported industrial firms in some of India's more prosperous industrial states and in states considered to provide a stable investment environment and good governance (Table 4). This reflects the fact that, as was observed above, some states have pursued far more proactive strategies through CDM cells to attract projects while others, such as Gujarat, have attractive policies in place including high tariffs for renewable electricity.

Previous studies have indicated that projects with foreign project participants are more likely to involve technology transfer (Das, 2011; Schneider et al. 2008; Seres, et al. 2009). This also seems to hold for India, as the rate of technology transfer among unilateral projects in India is lower (3 percent) than non-unilateral projects (12 percent) (Table 5). For the purpose of this study, a project is regarded as 'unilateral' if the PDD does not mention the existence of any foreign project participant or credit buyer. This does not preclude the possibility that a foreign project participant may later enter a project. However, for our analysis, we are concerned with the possibility of a foreign project participant influencing technology transfer-related decisions outlined in the PDD. That the large 
majority of Indian projects are unilateral ( 82 percent) is also consistent with the low rate of technology transfer in India. Among the 58 Indian projects with foreign project participants (18 percent), twelve involved public bodies, either multilateral/bilateral funds or foreign government entities. Some of these, such as the International Finance Corporation (IFC; four projects) have mandates to build the capacity of the private sector in emerging economies such as India. However, of these twelve projects, only one involved Type 3 technology transfer.

Table 4. Indian States hosting CDM Technology Transfer Projects

\begin{tabular}{|c|c|}
\hline States hosting Type 3 projects & States hosting Type $1 /$ Type 2 projects \\
\hline $\begin{array}{l}\text { Andhra Pradesh | Energy efficiency own generation } \\
\text { Gujarat | Energy efficiency in Industry; } \\
\text { Hydroflurocarbons } \\
\text { Maharashtra | Energy efficiency in Industry } \\
\text { Punjab | Biomass } \\
\text { Rajasthan | Fossil Switch; Hydroflurocarbons } \\
\text { Tamil Nadu | Wind; Hydroflurocarbons } \\
\text { Uttar Pradesh | Biomass } \\
\text { West Bengal | Energy efficiency in Industry }\end{array}$ & $\begin{array}{l}\text { Gujarat } \mid \text { Energy efficiency in Industry } \dagger \\
\text { Uttar Pradesh | Energy efficiency in } \\
\text { Industry } \dagger \\
\text { Various | Solar }\end{array}$ \\
\hline
\end{tabular}

Note: In all cases each state hosts one of each listed project type, other than $\uparrow:$ Gujarat and Uttar Pradesh each host one Type 2 Energy Efficiency in Industry project in addition to hosting separate units of the same cooperative-led fertilizer project described.

Table 5: Rate of Technology Transfer in Unilateral/ non-Unilateral Indian CDM projects

\begin{tabular}{lr}
\hline & \\
Total number of projects & 326 \\
\hline Unilateral projects & $268(82)$ \\
Non-unilateral projects & $58(18)$ \\
& \\
Total number of technology transfer projects & $16[5]$ \\
Unilateral technology transfer projects & $9[3]$ \\
Non-unilateral technology transfer projects & $7[2]$ \\
& 5 \\
\hline Percentage of projects with technology transfer : all projects & 3 \\
\hline Percentage of projects with technology transfer : Unilateral & 12 \\
\hline Percentage of projects with technology transfer : Non-unilateral & \\
\hline
\end{tabular}

\section{Discussion}


This analysis suggests that many previous assessments of the CDM overestimate the level of technology transfer in Indian CDM projects. This is particularly the case under conditions in which technology transfer includes an element of technological learning and capability building. We find that for the vast majority of Indian CDM projects involving technology transfer, technological learning is confined to the level of operational knowledge of an imported technology. In the isolated cases of superior technology transfer, the models of project development have been in spite of the CDM's incentive structure and governance, rather than as a result of them. These have either involved CDM finance for existing partnerships, or followed well established models of technology transfer in which state agencies assume the transaction costs and risks associated with more transformative projects (Forsyth 1999). As Byrne et al. (2011: 18) have suggested, 'Exceptional CDM projects that do manage to seed local innovative benefits underscore the weaknesses inherent in the more general pattern'.

We suggest that conventional approaches to measuring technology transfer under the CDM are not able to capture important processes of technological learning. Recent studies have described how the rate of technology transfer in the CDM is affected by a recipient firm's absorptive capacity associated with a particular technology (Haites et al. 2012). However, we have taken technology transfer to be a process of capability building, rather than the utilisation of existing capabilities and absorptive capacity. From this perspective, studies that attribute India's lower levels of technology transfer under the CDM to its existing technological skills and capacity are problematic (e.g. Murphy et al 2013). India's existing capabilities have enabled the country to exploit static advantages over Least Developed Countries, attracting significant sums of CDM finance and technological hardware to the Indian market. But existing absorptive capacity does not limit the process of enhancing technological capabilities.

Evidence from India's wind industry provides further insights into the relative contribution of the CDM to clean technology knowledge in India to date. Lema \& Lema (2013) provide evidence that $\mathrm{CDM}$ projects in India have utilised existing mechanisms of transfer - such as joint ventures or the use of foreign subsidiaries - rather than contributing to the diversification of routes to knowledge transfer as the wind market has matured. The development of these mechanisms and capabilities is closely associated with developments in India's technological and economic policy (Kathuria 2002; Lewis 2007; Ockwell et al. 2010; Lema \& Lema 2012). The CDM appears to have provided finance through existing mechanisms developed prior to CDM project planning. We suggest that while finance is - and will continue to be - important to the clean energy economy in India, the CDM cannot currently claim to add significant value to the role of domestic Indian initiatives and recipient efforts in developing technological knowledge and capabilities. 
In this respect, Byrne et al. (2011) have argued that the contribution of the CDM to technology transfer is ultimately limited by its framing of low carbon technology transfer as a problem of insufficient hardware and finance. The framing appears to preclude the creation of conditions for indigenous capability development and alternative low-carbon pathways. We find significant support for this position in our study, but critically our analysis also points to the role of governance in shaping how the potential benefits of technology transfer are directed and distributed under a market mechanism.

In seeking to understand the role of governance and thereby address the neglect of politics and institutions in previous studies, we have explored the connections between these patterns of technology transfer and the governance of the CDM. Within the structural constraints of the CDM model for technology transfer, we find a de facto lack of attention to sustainable development criteria (a characteristic of the CDM market that is not limited to India) and a failure to use the CDM to lever forms of technology transfer that are supportive of other national initiatives on renewable energy or energy efficiency, among others. This is despite the fact that the model of governance overseen by the CDM provides significant opportunities for the state to improve the development dividend of CDM projects through formal and informal processes. Institutions at all levels are able to set priorities (through Technology Needs Assessments, for example) and negotiate benefits from technology (such as capacity-building, access, affordability and employment), given the requirement to demonstrate a contribution to sustainable development. At the same time, investor perceptions of individual states governance capacity within India (often understood as ease of doing business) appear to shape where they channel their CDM investments (Phillips and Newell 2013). These make public governance of the CDM at the national level important in determining the extent to which CDM projects do or do not promote technology transfer.

For now, however, the lack of clear steering at the national level and weak capacity at the state and local level to shape and negotiate improved technology outcomes in India means that a lower level of technology transfer prevails, primarily guided by considerations of firm strategy. This has been in spite of high expectations in India of what technology transfer will deliver for the country's industry. In the vacuum left by India's laissez-faire approach to building technological capabilities, questions of corporate strategy operate as more central drivers of technology transfer. The particular structures of the CDM have been instrumental in creating these conditions and incentive structures. As evidence from Malaysia has shown, however, prescriptive CDM project development criteria alone are insufficient to promote technological capability building (Hansen 2011). Instead, adopting a broader analysis of CDM governance, as we have done here, highlights the importance of a much broader range of state and private institutions and actors operating across different levels that play a part in governing technology under the CDM. By shaping investor expectations, screening projects, 
privileging particular technologies and types of transfer and negotiating terms, a range of domestic and international, public and private actors operating in formal and informal ways, structure the context in which technology transfer is expected to occur.

It is in this broader political context that the CDM may add value to potentially more significant efforts to use new technology in a transition to a low carbon economy. How countries identify and pursue technological priorities are political issues in themselves. Needs assessments are not valueneutral exercises but are shaped by existing power structures, historical experiences with particular technologies, and the socio-economic and cultural contexts in which technologies are mobilised (van der Gaast et al. 2009). Technological 'pathways' are built on such processes and their outcomes are strongly connected to the voices that participate in determining their direction (Leach et al. 2010). While it is precisely these forms of deliberation that are dis-incentivised by the current structure of the $\mathrm{CDM}$, they are also the basis on which low carbon technology transfer may be integrated into national and regional technology policies and aims, providing the basis for 'sensitive policies that seek to engage the major economic base of the nation or region with both indigenous and foreign technological capabilities' (Howells and Mitchie 1997:30; cited in Forsyth 1999: 255).

However, projects that potentially bridge the difficulties of combining deliberative processes with commercially viable project development have not been facilitated by the CDM (Forsyth 2007). While CDM finance has predominantly financed technology transfer in industrial sectors, development of absorptive capacity and innovation can equally be applied to projects with direct poverty reduction goals at community and household level, fostered through active partnerships between communities and investors (Forsyth 2007). It is important to note, for example, the role of technological capability building in projects that do not aim to produce great leaps of technological innovation but rather contribute to technological adaptation to local context and knowledge, beyond 'diffusion' of hardware (Ockwell 2012). The handful of cases of superior technology transfer in the Indian CDM signal how more ambitious knowledge sharing projects have been backed by state donors, 'boutique' carbon certification standards, existing corporate and cooperative relationships with foreign firms, and in-house technological development units. These projects highlight the level of additional investment of time, effort and costs by project developers, the support to the CDM market that has been required to allow these CDM projects to be developed, and how these projects represent exceptions to the rule. While ostensibly a market mechanism, the success stories of the technology transfer under the CDM in India highlight the limits of expecting the (CDM) market alone to instigate technological capability building.

The same is true for capturing and realising the broader co-benefits of the CDM which in theory underpin India's climate change strategy, particularly in managing the trade-offs between some forms 
of technology transfer and their social and environmental impacts. Governance is important to squaring technology transfer with other potential sustainable development priorities such as poverty alleviation, improvements in health, or energy access. For example, Hydroflurocarbon (HFC) projects and industrial sponge iron plants that have demonstrated Type 3 technology transfer raise serious concerns over limited local benefits, and evidence of the abuse of land rights and appropriation of natural resources from local residents (Lohmann 2006). Local governance institutions such as Gram Panchayats could play a role here but, in reality, their input is largely restricted to consultation processes on individual projects and tends to invoke little engagement with the terms of technology transfer, rather than a more pro-active form of engagement. Nevertheless, a lack of adequate consultation or consent has often been a key source of complaint in CDM projects that supply finance to large public and private industrial companies already in dispute with communities over industrial projects (Lohmann 2006; Böhm and Dhabi 2010) and there is currently a notable absence of mechanisms to ensure that communities actively benefit from technology transfer under the CDM, for example through pro-poor development, deliberative processes or diffusion and adaptation of household energy solutions.

Our argument with respect to building technological capabilities is based on a normative assumption that climate finance mechanisms should facilitate developing countries in gaining greater control over their own low-carbon pathways. Given the uncertainties over the future of the CDM, there are also strong arguments in favour of eschewing concepts of technology 'transfer' in favour of policies for capability building (Byrne et al. 2011; Lema and Lema 2012; Ockwell and Mallett 2012). Indeed, new international mechanisms such as the UNFCCC Technology Mechanism that are specifically designed to encompass research and development, demonstration, deployment, diffusion and transfer of climate change-related technologies may be more amenable to the adoption of a more relevant understanding of the slow and complex process of technological learning, than the narrow focus on linear models of technology transfer (Sampeth and Roffe 2012).

Finally, in terms of advancing future research in this area, the study has illustrated the potential value of using mixed methods in the study of carbon markets and technology transfer, combining the breadth and comparative analysis brought by quantitative methods with the specificity and complexity of politics captured by qualitative methods. Our discussion has also underscored the value of broader approaches to analysing governance that enable us to understand the roles of a range of public and private actors operating across a range of arenas, which go beyond exclusively state-based or marketbased accounts of CDM governance and technology transfer. We have also suggested the benefits of applying a more political analysis of governance to issues that are often reduced to questions of institutional capacity or technical design and to understanding the relations of power which shape 
governance and decision-making around technology that cannot be captured in enumeration and regression analysis.

\section{Conclusion}

This paper has suggested that, broadly conceived, CDM governance, through its presence and absence, plays an important role in producing the current form of the CDM market in India, in which the building of indigenous technological capabilities has been neglected. However, if the CDM and other market mechanisms are to continue to play a role in generating significant flows of finance, they should be engaged in the redistribution of skills and capabilities in low carbon technologies. As one observer has noted, 'We would like to see the CDM bringing in the right technologies, but the real reorientation of strategies and technical change has not happened' (Interview with Director of Climate Change, Indian Research Organisation). Structural constraints on the use of the CDM for development outcomes are significant, but the governance of the CDM and the politics of technology and energy potentially have significant mediating effects on the generation and distribution of CDM benefits and costs. We conclude that CDM host countries have scope to exercise a degree of agency in their engagement with the CDM. However, realising the potential for more transformative forms of technological development in CDM host countries requires attention to political relationships across a number of scales, and the power relations that govern the everyday functioning of the CDM.

\section{References}

Bell, M. (2009) Innovation Capabilities and Directions of Development. STEPS Working Paper 33. STEPS Centre, Brighton.

Benecke, G. (2009) Varieties of carbon governance: Taking stock of the local carbon market in India. Journal of Environment and Development 18(4), 346-370

Blanco, G., de Coninck, H. and Würtenberger, L. (2012) The Technology Mechanism under the UNFCCC: Ways Forward. Climate Strategies Policy Brief. October.

Boyd, E. (2009) Governing the Clean Development Mechanism: global rhetoric versus local realities in carbon sequestration projects. Environment and Planning A (41), 2380- 2395.

Böhm, S. and Dabhi, S. (eds) (2009) Upsetting the Offset: The Political Economy of Carbon Markets. Mayfly Books, Colchester.

Byrne, R., Smith, A., Watson, J. and Ockwell, D.G. (2011) Energy Pathways in Low-Carbon Development: From Technology Transfer to Socio-Technical Transformation. STEPS Working Paper 46. STEPS Centre, Brighton.

CIF [Climate Investment Funds], 2011. CTF Investment Plan for India. Meeting of the Clean Technology Fund Trust Fund Committee, Washington, D.C. CTF/TFC.8/4.

Cohen, W. M. and Levinthal, D. A. (1989). Innovation and learning: Two faces of R\&D. Economic Journal 99, 569-596.

Cohen, W. M., and Levinthal, D. A. (1990). Absorptive capacity: A new perspective on learning and innovation. Administrative Science Quarterly 35, 128-152.

CSE [Centre for Science \& Environment] (2010) Challenge of the New Balance: A Study of the Six Most Emissions Intensive Sectors to Determine India's Low Carbon Growth Options. Centre for Science and Environment, Delhi. 
Das, K. (2011) Technology transfer under the clean development mechanism: An empirical study of 1000 CDM projects. Working Paper 014, The Governance of Clean Development Working Paper Series. University of East Anglia, Norwich.

de Coninck, H., Haake, F., and Van Der Linden, N. (2007) Technology transfer in the Clean Development Mechanism. Climate Policy 7(5), 444-456.

Dechezleprêtre, A., Glachant, M. and Ménière, Y. (2008). The Clean Development Mechanism and the international diffusion of technologies: An empirical study. Energy Policy 36, 1273-83.

Dechezleprêtre, A., Glachant, M. and Ménière, Y. (2009) Technology Transfer by CDM Projects: A Comparison of Brazil, China, India and Mexico. Energy Policy 37, 703-711.

Dechezleprêtre, A., Glachant, M., Hascic, I., Johnstone, N. and Ménière, Y. (2011). Invention and Transfer of Climate Change Mitigation Technologies: A Global Analysis. Review of Environmental Economics and Policy 5(1), $109-130$

Disch, D. (2010) A comparative analysis of the 'development dividend' of Clean Development Mechanism projects in six host countries. Climate and Development 2, 50-64.

Forsyth, T. (1999) Flexible mechanisms of climate technology transfer. Journal of Environment \& Development 8(3): 238-257.

Forsyth, T. (2007) Promoting the "development dividend of climate technology transfer: Can crosssector partnerships help? World Development 35(10): 1684-1698.

$\mathrm{Fu}$, Xiaolan, Carlo Pietrobelli and Luc Soete (2011), The role of foreign technology and indigenous innovation in the emerging economies: technological change and catching-up. World Development 39(7), 1204-12.

Fuhr, H., and Lederer, M., (2009) Varieties of carbon governance in newly industrializing countries. Journal of Environment and Development, 18 (4), 327-346. Government of India (2008) National Action Plan on Climate Change. Government of India, Delhi.

Haites, E., Duan, M. and Seres, S. (2006) Technology Transfer by CDM Projects. Climate Policy 6(3), 327-344.Haites, E., Kirkman, G.A., Murphy, K., Seres, S. (2012) Technology transfer and the CDM. In D.G. Ockwell and A. Mallett (eds.) Low Carbon Technology Transfer: From Rhetoric to Reality. Earthscan, London.

Hansen, U. (2011) An empirical case study of the transfer of GHG mitigation technologies from Annex 1 countries to Malaysia under the Kyoto Protocol's clean development mechanism (CDM). International Journal of Technology Transfer and Commercialisation 10(1), 1-20.IPCC [Intergovernmental Panel on Climate Change] (2000). IPCC Special Report: Methodological and Technological Issues in Technology Transfer - Summary for Policy Makers. A Special Report of the Intergovernmental Panel on Climate Change, Working Group III. IPCC, Geneva.

Kathuria, V (2002) Technology transfer for GHG reduction: A framework with application to India. Technological Forecasting \& Social Change 69, 405-30.

Lall, S. (1992) Technological capabilities and industrialization. World Development 20(2), 165-86.

Lall, S. (1993) Understanding technology development. Development and Change 24(4), 719-53.

Lall, S. (2002) Linking FDI and technology development for capacity building and strategic competitiveness. Transnational Corporations 11(3), 39-88.Lall, S. (2004) Reinventing Industrial Strategy: The Role of Government Policy in Building Industrial Competitiveness., G24 Discussion Paper Series, Intergovernmental Group of Twenty-Four, United Nations Conference on Trade and Development, United Nations, New York and Geneva.

Leach, M., Scoones, I., and Stirling, A. (2010) Dynamic Sustainabilities: Technology, Environment, Social Justice. Earthscan, London.

Lema, R. and Lema, A. (2012) Technology transfer? The rise of China and India in green technology sectors. Innovation and Development 2(1), 23-44.

Lema, A. and Lema, R. (2013) Technology transfer in the clean development mechanism: Insights from wind power. Global Environmental Change 23: 301-313.

Lewis, J. I. (2007) A Comparison of Wind Power Industry Development Strategies in Spain, India and China. Centre for Resource Solutions, San Francisco.

Li, X. (2011) Sources of external technology, absorptive capacity, and innovation capability in Chinese state-owned high-tech enterprises. World Development 39(7), 1240-48. 
Lohmann, L. (2006) Carbon Trading: A Critical Conversation on Climate Change, Privatisation and Power. Das Hammarskjöld Foundation, Uppsala.

Mallet, A., Ockwell, D.G., Pal, P., Kumar, A., Abbi, A., Haum, R., Mackerron, G., Watson, J. and Girish, S. (2009) UK-India Collaborative Study on the Transfer of Low Carbon Technology: Phase II Final Report. Science \& Technology Policy Research Unit, University of Sussex and the Energy and Resources Institute (TERI), Brighton and New Delhi.

Martinot, E., Sinton, J. And Haddad, B. (1997) International technology transfer for climate change mitigation and the cases of Russia and China. Annual Review of Energy and the Environment 22: 357-402

Michaelowa, A. and Purohit, P. (2007) Additionality Determination of Indian CDM projects: Can Indian CDM Project Developers Outwit the CDM executive board? Climate Strategies, Cambridge.

Nelson, R. and Winter (1982) An Evolutionary Theory of Economic Change. Harvard University Press. Cambridge.

MoEF [Ministry of Environment and Forests] (nd) Host Country Approval Eligibility Criteria. Available online: http://envfor.nic.in/cdm/host approval criteria.htm, accessed 13 February 2012.

MoEF (2012) India Second National Communication to the United Nations Framework Convention on Climate Change. Ministry of Environment and Forests, Delhi.

Mowery, D.C. and Rosenberg, N. (1989) Technology and the Pursuit of Economic Growth. Cambridge University Press, Cambridge.

Murphy, K., Kirkman, G.A, Seres, S. \& Haites, E. (2013) Technology transfer in the CDM: an updated analysis, Climate Policy, DOI: 10.1080/14693062.2013.812719

Nelson, R. R. and Winter, S. J. (1982). An Evolutionary Theory of Economic Change. Harvard University Press, Cambridge.

Newell, P., Jenner, N. and Baker, L. (2009) Governing clean development: A framework for analysis. Development Policy Review 27(6), 717 - 739.

Ockwell, D.G. (2012) Adapting Energy Policy for Climate Change: Challenges and Opportunities for LDCs, SVEs and SIDS. Commonwealth Secretariat, London.

Ockwell, D. G. and Mallet, A. (eds.) (2012) Low Carbon Technology Transfer: From Rhetoric to Reality. Routledge, Abingdon.

Ockwell, D.G., Haum, R., Mallett, A., and Watson, J. (2010) Intellectual property rights and low carbon technology transfer: Conflicting discourses of diffusion and development. Global Environmental Change 20, 729-738.

Phillips, J. and Newell, P. (2013) The governance of clean energy in India: The clean development mechanism (CDM) and domestic energy politics. Energy Policy 59: 654-662

Planning Commission (2003) Report of the Working Group on National Action Plan for Operationalising Clean Development Mechanism (CDM) in India. Government of India, Delhi.

Planning Commission (2011) Interim Report of the Expert Group on Low Carbon Strategies for Inclusive Growth. Government of India, Delhi.

Sampeth, P.G and Roffe, P. (2012) Unpacking the International Technology Transfer Debate: Fifty Years and Beyond. ICTSD Working Paper, June. International Centre for Trade and Sustainable Development, Geneva.

Schiermeier, Q. (2011) Clean energy credits tarnished. Nature 477, 517-518.

Schmid, G. (2012) Technology transfer in the CDM: the role of host-country characteristics. Climate Policy 12(6), 722-740.

Schneider, M., Holzer, A., and Hoffman, V. (2008) Understanding the CDM's contribution to technology transfer. Energy Policy 36, 2930-38

Seres, S. et al. (2007). Analysis of Technology Transfer in CDM Projects. United Nations Framework Convention on Climate Change.

Seres, S. and Haites, E. (2008) Analysis of Technology Transfer in CDM Projects. United Nations Framework Convention on Climate Change, Bonn.

Seres, S., Haites, E. and Murphy, K. (2009) Analysis of technology transfer in CDM projects: An update. Energy Policy 37, 4919-4926. 
Sirohi, S. (2007) CDM: Is it a 'win-win' strategy for rural poverty alleviation in India? Climatic Change 84, 91-110.

TERI [The Energy and Resources Institute] (2005) CDM Implementation in India: The National Strategy Study. The Energy and Resources Institute, Delhi.

UNFCCC (2010). The Contribution of the Clean Development Mechanism under the Kyoto Protocol to Technology Transfer. United Nations Framework Convention on Climate Change, Bonn.

UNFCCC (2011a) Benefits of the Clean Development Mechanism 2011. United Nations Framework Convention on Climate Change, Bonn.

UNFCCC (2011b) Proposals by India for Inclusion of Additional Agenda Items in the Provisional Agenda of the Seventeenth Session of the Conference of the Parties. FCCC/CP/2011/INF.2/Add.1. 7 October 2011. Available at: http://moef.nic.in/downloads/public-information/inf02a01.pdf, accessed 30 November 2012.

UNFCCC (2012) Benefits of the Clean Development Mechanism 2012. United Nations Framework Convention on Climate Change, Bonn.

van der Gaast, W., Begg, K. and Flamos, A. (2009) Promoting sustainable energy technology transfers to developing countries through the CDM. Applied Energy 36, 230-236.

Vihma, A. (2011) India and the global climate governance: Between principles and pragmatism. Journal of Environment \& Development 20(1), 69-94.

Wang, B. (2010). Can CDM bring technology transfer to China? An empirical study of technology transfer in China's CDM projects. Energy Policy 38, 2572-85.

Wara, M. (2007) Is the global carbon market working? Nature 445, 595-596.

Watson, J., Byrne, R., Mallett, A. Stua, D., Ockwell, D.G., Xiliang, Z., Da, Z., Tianhou, Z. Xiaofeng, Z. And Xunmin, O. (2011) UK-China Collaborative Study on Low Carbon Technology Transfer. Final Report for the UK Department of Energy and Climate Change. SPRU and Laboratory for Low Carbon Energy, Brighton and Beijing.

Yang, M. (2006), Energy efficiency policy impact in India: Case study of investment in industrial energy efficiency. Energy Policy, 34, 3104-14. 